\title{
Abnormal Kainate Receptor Expression in Prefrontal Cortex in Schizophrenia
}

\author{
James H. Meador-Woodruff, M.D., Kenneth L. Davis, M.D., and Vahram Haroutunian, Ph.D.
}

\begin{abstract}
Abnormalities of molecules associated with the glutamate synapse have been implicated in the pathophysiology of schizophrenia. Of the many glutamate receptors, those most commonly suggested to be involved in schizophrenia are the ionotropic subtypes, the NMDA, AMPA, and kainate receptors. Both the NMDA and AMPA subtypes have been extensively studied in postmortem brains of individuals with schizophrenia, but relatively little is known about the expression of the kainate subtype of glutamate receptor. In this study, we have determined cortical and striatal kainate receptor expression in brains from persons with schizophrenia and a comparison group, using both in situ hybridization and receptor autoradiography. At the level of subunit mRNA expression, a shift in subunit stoichiometry was evident in multiple regions of the prefrontal cortex,
\end{abstract}

with increased expression of gluR7 $m R N A$ and decreased expression of KA2 mRNA. Decreased kainate receptor binding was also observed in the subjects with schizophrenia, but was restricted to infragranular laminae of the prefrontal cortex. No differences in kainate receptor binding or subunit mRNA levels were found in striatum or occipital cortex, suggesting that these findings may be restricted to association cortex. These data add to the growing literature implicating ionotropic glutamate receptor disturbances in schizophrenia, and indicate that in addition to AMPA and NMDA receptors, the kainate receptors are also abnormally expressed in this illness. [Neuropsychopharmacology 24:545-552, 2001] (C) 2001 American College of Neuropsychopharmacology. Published by Elsevier Science Inc.
KEY WORDS: Glutamate; Prefrontal cortex; Striatum; In situ hybridization; Receptor autoradiography; Ionotropic glutamate receptors

A growing literature suggests glutamatergic dysfunction in schizophrenia. Perhaps the strongest evidence for glutamatergic involvement in this illness is that dissociative anesthetics, especially phencyclidine and ket-

Published online on August 9, 2000 at http://www.acnp.org/ citations/Npp08080001.

From the Mental Health Research Institute and Department of Psychiatry (JHMW), University of Michigan, Ann Arbor, MI; and the Department of Psychiatry (KLD, VH), Mount Sinai School of Medicine, New York, NY.

Address correspondence to: James H. Meador-Woodruff, M.D., Mental Health Research Institute, Department of Psychiatry, University of Michigan, 205 Zina Pitcher Place, Ann Arbor, MI 48109-0720, Tel.: (734) 936-2093, Fax: (734) 647-4130, E-mail: jimmw@umich.edu

Received February 14, 2000; revised August 1, 2000; accepted August 7, 2000. amine, can cause a schizophreniform psychosis in normal humans, and worsen psychotic symptoms in persons with schizophrenia (Itil et al. 1967; Javitt and Zukin 1991; Krystal et al. 1994; Lahti et al. 1995; Luby et al. 1962). These drugs are uncompetitive inhibitors of the NMDA subtype of glutamate receptor, suggesting that schizophrenia may be associated with decreased NMDA receptor activity (Javitt and Zukin 1991; Carlsson and Carlsson 1990). Further, facilitators of NMDA receptor activity have been shown to improve psychotic symptoms. Since direct agonists of this receptor are neurotoxic, other therapeutic strategies have been used to enhance NMDA receptor activity. Agonists at the glycine co-agonist site of the NMDA receptor have been found to improve negative psychotic symptoms, providing additional support for diminished NMDA receptor activity in schizophrenia (Goff et al. 1995; Goff et al. 1999; Heresco-Levy et al. 1999; Javitt et al. 1994).

In addition to the NMDA subtype, however, there 
are additional families of cation-selective ionotropic glutamate receptors, the AMPA and kainate subtypes. Although the NMDA receptor is the subtype of glutamate receptor usually implicated in schizophrenia, the other ionotropic glutamate receptors also may be abnormal in this illness; abnormalities. While a growing literature suggests abnormal expression of both NMDA and AMPA receptors in the brain in schizophrenia (reviewed in Meador-Woodruff and Healy 2000), much less is known about potential abnormalities of the kainate receptor in this illness. The ionotropic glutamate receptors share a common structural motif, and are each composed of four or five family-specific subunits that form ligandgated ion channels (Hollmann and Heinemann 1994). Kainate receptors are composed of the low affinity gluR5, gluR6, and gluR7 subunits, and the high affinity KA1 and KA2 subunits (Hollmann and Heinemann 1994). The gluR5, gluR6, and gluR7 subunits assemble into homomeric complexes, or heteromerically coassemble with KA1 and KA2, resulting in receptors with distinct pharmacological properties, suggesting that subunit composition, at least in part, determines the functional properties of the kainate receptor (Lerma 1998).

Only several studies have examined the kainate-associated subunits in schizophrenic brain. Decreased expression of gluR6 and KA2 mRNA were noted in several hippocampal regions, although gluR6 mRNA was not found to be changed in the cerebellum in schizophrenia in this same study (Porter et al. 1997). A recently published study suggested that gluR7 and KA1 subunit transcripts are decreased in the superior frontal gyrus in schizophrenics, similar to decreases also noted by this investigator for some of the subunits associated with the AMPA and NMDA receptors (Sokolov 1998). Only one study to date has examined any of the kainate subunit proteins: gluR5 was studied by Western analysis, and was not changed in the hippocampus (Breese et al. 1995). Kainate receptor binding has been studied in multiple brain regions in schizophrenia by several independent groups. $\left[{ }^{3} \mathrm{H}\right]$ kainate binding has been reported to be elevated in multiple cortical areas in schizophrenia (Deakin et al. 1989; Nishikawa et al. 1983), decreased in the hippocampus and parahippocampal gyrus (Kerwin et al. 1990), and unchanged in striatal regions (Nishikawa et al. 1983; Noga et al. 1997). Although the available data for the kainate receptor in schizophrenia are sparse, in general, this receptor has a pattern of abnormal expression similar to that seen for the AMPA receptor.

Given the paucity of data directly examining the expression of the kainate receptor in the brain in schizophrenia, in this study we have determined prefrontal cortical and striatal kainate receptor expression in brains from persons with schizophrenia and a comparison group, using both in situ hybridization and receptor autoradiography. Our hypothesis is that altered kainate receptor expression is present in schizophrenia in prefrontal cortex or striatum, detectable at the levels of subunit mRNA and receptor binding.

\section{METHODS}

\section{Subjects}

Fifteen subjects with schizophrenia and a comparison group of nine individuals were studied. These same subjects were studied in our earlier work on dopamine and AMPA receptor expression in schizophrenia (MeadorWoodruff et al. 1997; Healy et al. 1998). There were no statistically significant differences for age $(\mathrm{t}=1.7, p=$ $.09)$, postmortem interval (PMI) $(\mathrm{t}=2.0, p=.06)$, tissue $\mathrm{pH}(\mathrm{t}=1.8, p=.09)$, freezer storage time $(\mathrm{t}=1.3, p=.2)$ or sex $\left(\mathrm{X}^{2}=0.05, p=.8\right)$ between the two groups (Table 1). At autopsy, the subjects' brains were removed and one hemisphere was examined by a neuropathologist. There was evidence of neuropathology in two of the subjects with schizophrenia (small cerebral infarcts in regions not under study), but none in the controls. The other hemisphere was dissected into $1-\mathrm{cm}$ slabs in the coronal plane. These blocks were rapidly frozen and stored at $-80^{\circ} \mathrm{C}$ until cryostat sectioned. Prefrontal cortical blocks were at a level $5 \mathrm{~cm}$ caudal to the frontal pole, and contained Brodmann areas (BA) 9, 11,32, and 46; the rostral extent of BA8 was present on a few of the blocks, but was not studied in this work. Occipital cortical blocks contained BA17 exclusively, and were from a slab $2-3 \mathrm{~cm}$ rostral to the occipital pole of the brain. Striatal blocks contained caudate, putamen, and nucleus accumbens.

\section{In situ hybridization}

In situ hybridization for the transcripts encoding the kainate receptor subunits was performed as previously

Table 1. Demographic Details of Subjects

\begin{tabular}{lcc}
\hline & $\begin{array}{c}\text { Comparison group } \\
\mathbf{( N = \mathbf { 9 } )}\end{array}$ & $\begin{array}{c}\text { Subjects with Schizophrenia } \\
\mathbf{( N = 1 5 )}\end{array}$ \\
\hline Age & $81 \pm 14$ & $74 \pm 9$ \\
Sex (M/F) & $3 / 6$ & $7 / 8$ \\
Postmortem interval (h) & $4.7 \pm 2.7$ & $8.7 \pm 5.4$ \\
Brain pH & $6.1 \pm 0.4$ & $6.4 \pm 0.4$ \\
Freezer storage time (years) & $5.8 \pm 1.2$ & $6.4 \pm 0.9$ \\
\hline
\end{tabular}


described (Meador-Woodruff et al. 1997; Healy et al. 1998). Riboprobes were synthesized from linearized plasmid DNA containing subclones of kainate receptor subunits, as summarized Table 2. These subclones correspond to regions common to all splice and mRNA editing variants of each subunit. Riboprobes were synthesized using $100 \mu \mathrm{Ci}$ of dried $\left.{ }^{35} \mathrm{~S}\right]-\mathrm{UTP}, 2.0 \mu \mathrm{l} 5 \times$ transcription buffer, $1.0 \mu \mathrm{l} 0.1 \mathrm{M}$ DTT, $1.0 \mu \mathrm{l}$ each of $10 \mathrm{mM}$ ATP, CTP, and GTP, $2.0 \mu l$ linearized plasmid DNA, 0.5 $\mu l$ RNase inhibitor, and $1.5 \mu \mathrm{T}$ T3 or T7 RNA polymerase incubated for two hours at $37^{\circ} \mathrm{C}$. After this incubation, 1.0 $\mu l$ DNase (RNase-free) was added and incubated for 15 minutes at room temperature. The reaction mixture was then sieved through a 1-cc syringe containing G-50 Sephadex equilibrated in Tris buffer (100 mM Tris- $\mathrm{HCl}$, pH 7.5, 12.5 mM EDTA, pH 8.0, $150 \mathrm{mM} \mathrm{NaCl}$, and $0.2 \%$ SDS), and $100 \mu \mathrm{l}$ fractions were eluted. DTT was added to each fraction to a final concentration of $0.01 \mathrm{M}$.

Two slides per subject for each probe were removed from $-80^{\circ} \mathrm{C}$ storage and placed in $4 \%$ (weight:vol) formaldehyde at room temperature for one hour. The slides were then briefly washed in $2 \times \mathrm{SSC}(300 \mathrm{mM} \mathrm{NaCl} / 30$ $\mathrm{mM}$ sodium citrate, $\mathrm{pH}$ 7.2) three times. The slides were then placed in $0.1 \mathrm{M}$ triethanolamine, $\mathrm{pH} 8.0$ /acetic anhydride, 400:1 (vol:vol), on a stir plate, for 10 minutes. The final wash was in $2 \times$ SSC buffer for five minutes, followed by dehydration through graded alcohols and air drying. A cover slip with radiolabeled riboprobe (2$8 \times 10^{6} \mathrm{cpm}$ ) $/ 50 \%$ formamide buffer/0.01M DTT (500 $\mu \mathrm{l}$ per slide) was placed on each slide. Slides were placed in a covered tray with filter paper saturated with $50 \%$ formamide buffer, and incubated at $55^{\circ} \mathrm{C}$ overnight.

The next day the cover slips were removed and the slides were placed in $2 \times$ SSC for five minutes, followed by RNase $(200 \mu \mathrm{g} / \mathrm{ml}$ in $10 \mathrm{mM}$ Tris-HCl, $\mathrm{pH} 8.0 / 0.5 \mathrm{M}$ $\mathrm{NaCl})$ at $37^{\circ} \mathrm{C}$ for 30 minutes. The slides then underwent the following washes: $2 \times$ SSC at room temperature for 10 minutes; $1 \times$ SSC for 10 minutes at room temperature; $0.5 \times \mathrm{SSC}$ at $55^{\circ} \mathrm{C}$ for 60 minutes; and $0.5 \times$ SSC for 10 minutes at room temperature. Sections were dehydrated in graded alcohols and apposed to Kodak XAR-5 film for up to eight weeks.

\section{Receptor autoradiography}

Two slides (one for total and one for nonspecific binding) for each subject at each cortical and striatal level were re-

Table 2. Probes Used for In Situ Hybridization Studies

\begin{tabular}{lcc}
\hline Probe & Length $(\mathbf{b p})$ & Bases (relative to coding region) \\
\hline gluR5 & 765 & $-8: 757$ \\
gluR6 & 484 & $-200: 284$ \\
gluR7 & 865 & $-299: 566$ \\
KA1 & 607 & $-76: 531$ \\
KA2 & 469 & $-13: 456$ \\
\hline
\end{tabular}

moved from the $-80^{\circ} \mathrm{C}$ freezer and warmed at room temperature for 15 minutes. Slides then underwent a binding prewash in $50 \mathrm{mM}$ Tris-citrate $(\mathrm{pH} \mathrm{7.4)}$ at room temperature for 30 minutes to remove endogenous glutamate. Slides were rinsed in deionized water and dried under a stream of cool air. Slides were then incubated in $50 \mathrm{mM}$ Tris-citrate ( $\mathrm{pH}$ 7.4) containing $12 \mathrm{nM}$ $\left[{ }^{3} \mathrm{H}\right]$ kainate, which is three times $\mathrm{K}_{\mathrm{d}}$, as determined in this lab. Nonspecific binding was determined by adding $10 \mu \mathrm{M} C N Q X$ to the ligand buffer. After incubation, excess buffer was tapped off onto a paper towel, and slides were rinsed in fresh $50 \mathrm{mM}$ Tris-citrate $\left(\mathrm{pH} \mathrm{7.4)}\right.$ at $4^{\circ} \mathrm{C}$ three times. Slides were then briefly rinsed in deionized water at $4^{\circ} \mathrm{C}$ and dried under a stream of cool air. Slides were apposed to Amersham $\left[{ }^{3} \mathrm{H}\right]$ Hyperfilm for 28 days.

\section{Image analysis}

Images were acquired and stored by digitizing film images with a Macintosh-based CCD imaging system. Image analysis was performed using NIH Image 1.56. Striatal regions were readily identified based on gross morphological patterns. Brodmann areas were identified in the cortical sections by cresyl violet staining of adjacent sections from each subject, using standard histological criteria. For both the prefrontal and occipital cortical areas, both infragranular and supragranular laminae were sampled. In those cases in which a distinct granular layer was observed, image analysis was based on using this as a landmark for determining regions of interest. In those cases where the granular level was not clearly defined, infragranular laminae were estimated to be the inner third of the thickness of the cortical gray matter, while supragranular laminae were estimated as the outer third. For in situ hybridization images, gray scale values were obtained from striatal regions and infragranular and supragranular cortical laminae from each Brodmann area, corrected for tissue background, and converted to optical density. These values are linear with concentration over the gray scale values found in this study. Values from two sections for each subject were averaged and used for subsequent data analysis. For receptor binding images, gray scale values for striatal regions, and infragranular and supragranular cortical laminae were corrected for nonspecific binding, and converted to optical density.

\section{Statistical analysis}

Data were analyzed by repeated measures ANOVA for each block for each probe, resulting in 15 primary analyses $(6$ probes each in prefrontal and occipital cortex, 3 probes in striatum). In order to perform as few tests as possible, multivariate statistics were chosen; some cases had missing data points (32 missing cells out of a total of 1656 datapoints), and these cells were filled by using 

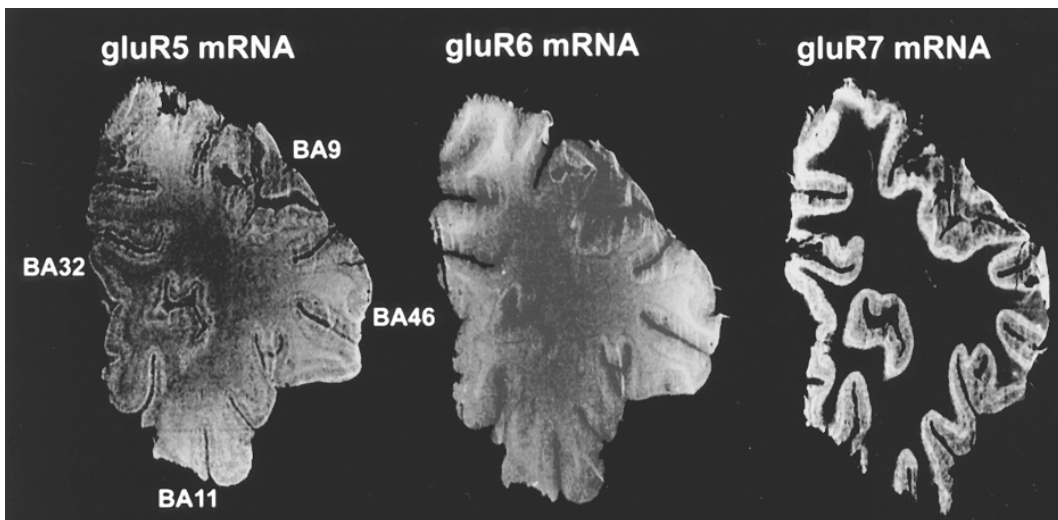

KA1 mRNA

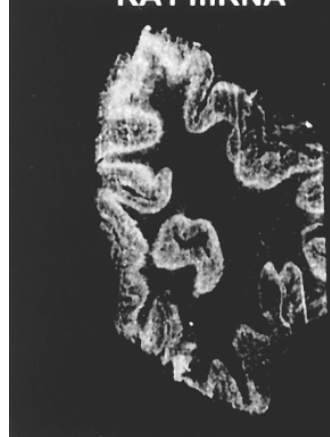

KA2 mRNA

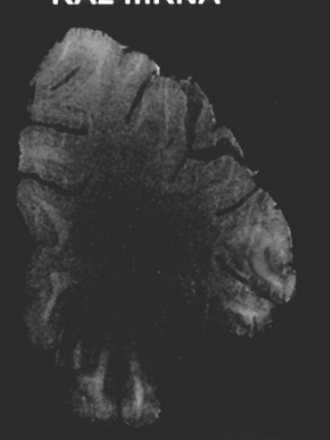

$\left[{ }^{3} \mathrm{H}\right]$ kainate

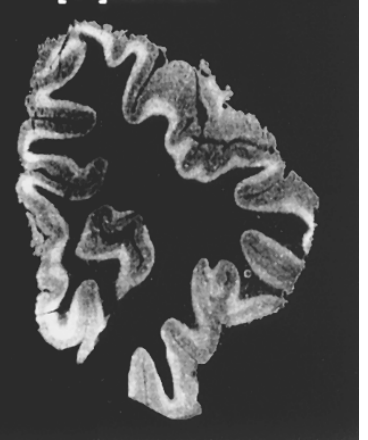

Figure 1. Kainate receptor subunit mRNA expression and $\left[{ }^{3} \mathrm{H}\right]$ kainate binding in prefrontal cortex. All five subunit mRNAs are detectable in cortical regions, although gluR7 and KA1 transcripts are by far the most abundant; the images for gluR5, gluR6 and KA2 have been enhanced to demonstrate the low levels of expression that are present. $\left[{ }^{3} \mathrm{H}\right]$ kainate binding is also present throughout the prefrontal cortex, and is enriched in infragranular layers. BA = Brodmann area. mean substitution to preserve the power of the multivariate tests. In prefrontal cortex, repeated measures ANOVA was performed for each probe, with diagnosis as the independent variable, and both BA and lamina (infra- and supragranular) treated as within-subject factors. In both striatum and occipital cortex, repeated measures ANOVA was performed for each probe, with diagnosis treated as the independent variable, and with a single within-subject factor (striatal region in the case of the striatal block, and laminae for the slides containing BA17). Post hoc analyses were performed using the Tukey HSD test for uneven sample sizes, and $\alpha=0.05$ for all tests of significance. Although there were no statistically significant differences of age, PMI, or tissue
$\mathrm{pH}$ between the two groups, these potentially confounding variables were used as covariates in a secondary analysis of these data, as each of these variables trended toward differences between the diagnostic groups. The same repeated measures design described above was used but in ANCOVAs; there were no differences in the outcome of these analyses regardless of whether these variables were treated as covariates.

\section{RESULTS}

All five kainate receptor subunit transcripts were present in cortex, although gluR5, gluR6, and KA2

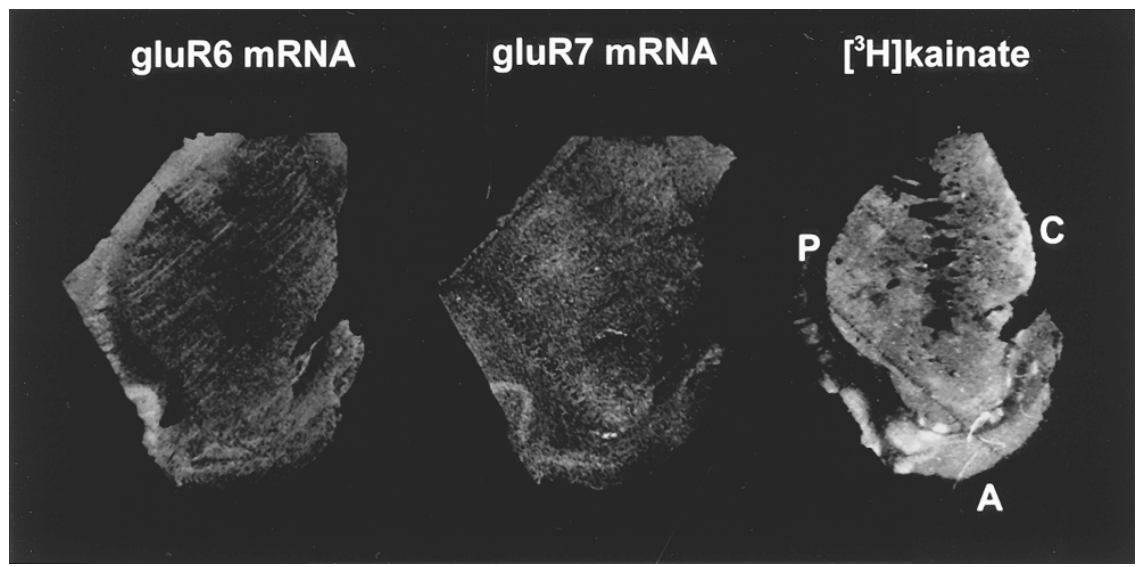

Figure 2. Kainate receptor subunit mRNA expression and $\left[{ }^{3} \mathrm{H}\right]$ kainate binding in striatum. Only gluR6 and gluR7 transcripts are detectable, and at very low levels of expression. [ $\left.{ }^{3} \mathrm{H}\right]$ kainate binding is detected at relatively higher levels throughout the regions of the striatal complex $(\mathrm{C}=$ caudate; $\mathrm{P}=$ putamen; $\mathrm{A}=$ nucleus accumbens). 

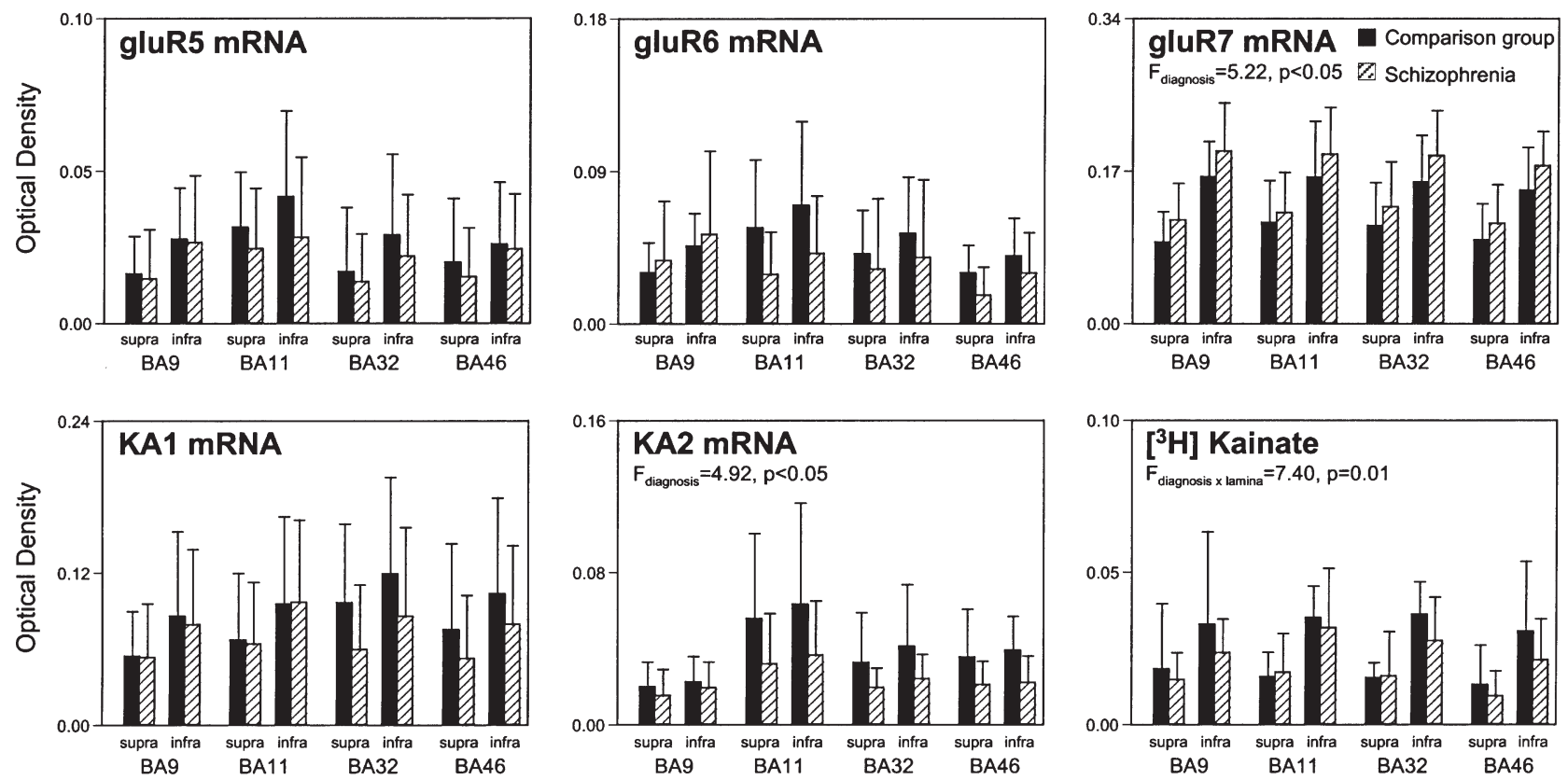

Figure 3. Kainate receptor subunit mRNA levels and $\left[{ }^{3} \mathrm{H}\right]$ kainate binding in prefrontal cortical regions of individuals with schizophrenia and a comparison group, expressed as mean optical density \pm standard deviation. Both gluR7 and KA2 mRNAs, as well as $\left[{ }^{3} \mathrm{H}\right]$ kainate binding, are significantly different between the two groups. "Supra" and "infra" refer to supra- and infragranular layers of each Brodmann area, as described in the text.

mRNA were present at much lower levels than gluR7 and KA1 transcripts (Figure 1). The striatal regions expressed very low levels of only gluR6 and gluR7 mRNA (Figure 2). Appreciable $\left[{ }^{3} \mathrm{H}\right]$ kainate binding was observed in cortical regions and in the striatum, as has been previously reported (Deakin et al. 1989; Nishikawa et al. 1983; Noga et al. 1997) (Figures 1 and 2).

In prefrontal cortical regions, gluR7 and KA2 mRNA levels were significantly different between the subjects with schizophrenia and the comparison group, while the other transcripts did not differ between these groups (Figure 3). For gluR7, there was a main effect for diagnosis $(\mathrm{F}=5.22 \mathrm{df}=1,19, p=.03)$ but no significant interactions of diagnosis with either BA or lamina. Post hoc analysis revealed that this difference was attributable to increases of gluR7 mRNA in the infragranular layers of all four Brodmann areas, and the supragranular layers of BA9, in the subjects with schizophrenia. There was also a significant main effect for diagnosis but no significant interactions for KA2 mRNA ( $\mathrm{F}=$ $4.92, \mathrm{df}=1,19, p=.04)$. Post hoc analysis indicated that this was associated with decreased expression in schizophrenia in both laminar zones in BA11, 32, and 46. In the subjects with schizophrenia, $\left[{ }^{3} \mathrm{H}\right]$ kainate binding was also decreased (diagnosis $\times$ lamina $\mathrm{F}=7.40$, $\mathrm{df}=1,22, p=.01)$, which was specifically associated with the infragranular layers $(p=.002)$ (Figure 3 ).

There were no differences between diagnostic groups for any of the kainate subunit transcripts or $\left[{ }^{3} \mathrm{H}\right]$ kainate binding in either striatum (Figure 4) or BA17 (Figure 5).

\section{DISCUSSION}

Our data suggest that there is altered stoichiometry in the expression of the transcripts encoding the kainate receptor subunits in prefrontal cortex in schizophrenia.
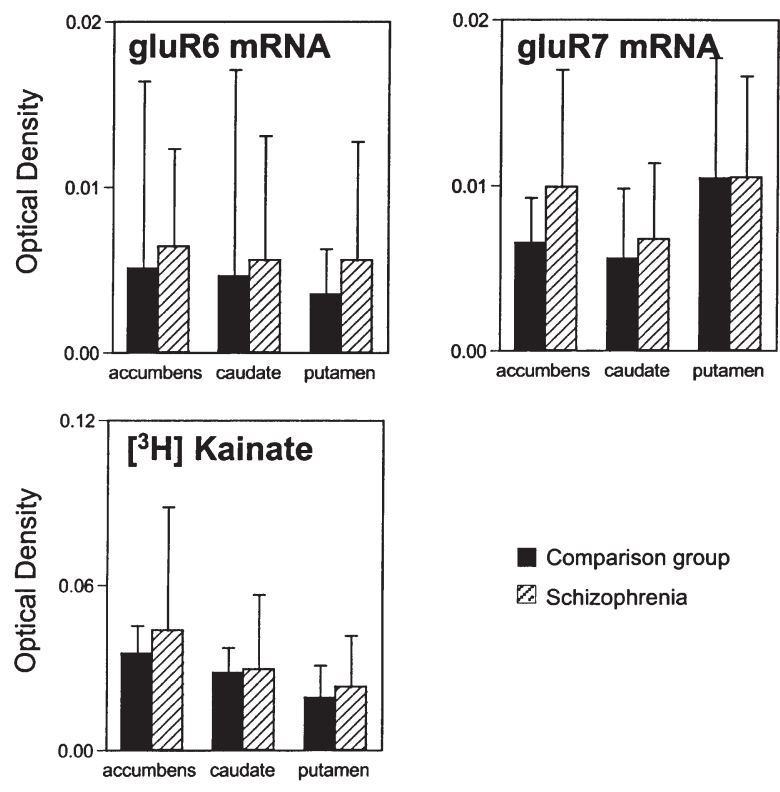

Comparison group C. Schizophrenia

Figure 4. Kainate receptor subunit mRNA levels and $\left[{ }^{3} \mathrm{H}\right]$ kainate binding in striatal regions, expressed as mean optical density \pm standard deviation. There are no significant between-group differences. 

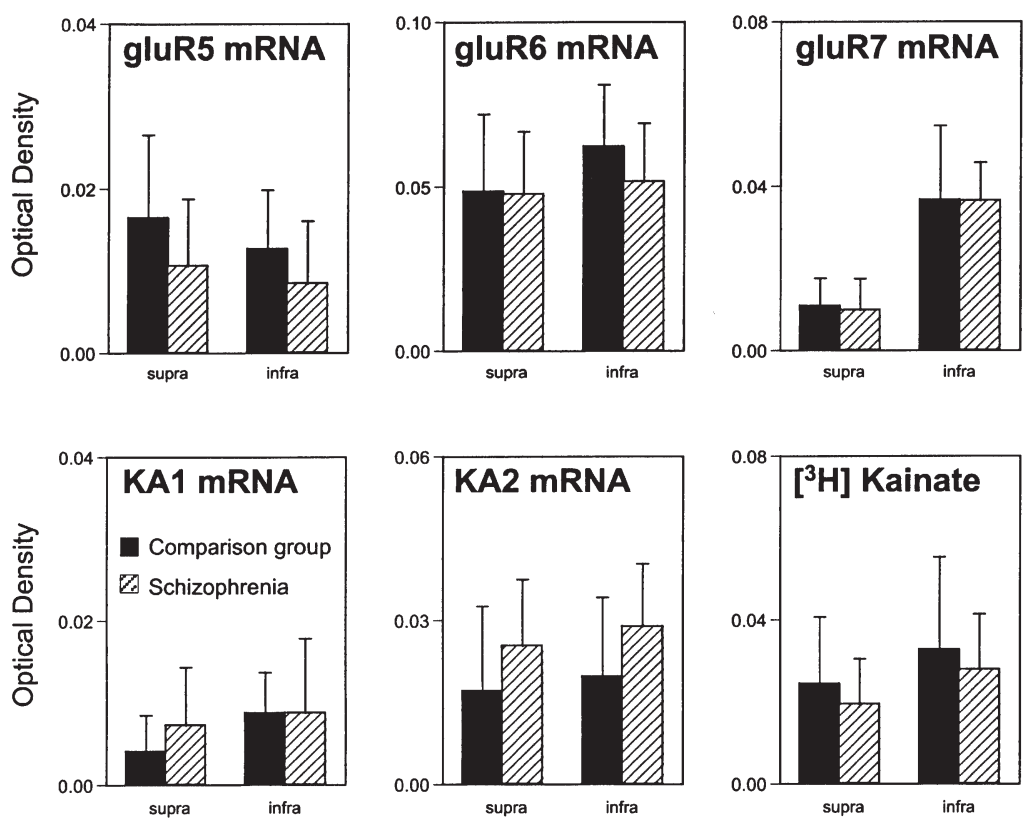

Figure 5. Kainate receptor subunit mRNA levels and $\left[{ }^{3} \mathrm{H}\right]$ kainate binding in BA17, expressed as mean optical density \pm standard deviation. There are no significant betweengroup differences.
There was a decrease in KA2 mRNA and an increase in gluR7 mRNA levels in the prefrontal cortex of the subjects with schizophrenia. A decrease in cortical kainate receptor binding was also observed in the schizophrenic group, but restricted to the deeper cortical layers. We found no differences in kainate receptor binding or subunit mRNA levels in striatum or BA17 in schizophrenia.

Relatively few studies have examined the expression of the kainate receptor subunits in schizophrenia, and there are no earlier studies in which all of the kainate receptor subunits have been measured in the same brains. Similar to our findings in prefrontal cortex, Porter and colleagues (1997) found decreased expression of KA2 subunit mRNA in several hippocampal subfields in schizophrenia. In addition, they reported decreased levels of gluR6 mRNA in medial temporal lobe structures but not in cerebellum. Sokolov (1998) found decreased expression of both gluR7 and KA1 mRNA in superior temporal cortex in schizophrenia, although the other kainate subunits were not studied; the gluR7 observation is opposite what we have found in the current study. It is possible that there are region-specific changes of this subunit in different neocortical areas that account for this apparent discrepancy, although the difference may be due to the different techniques used to quantitate mRNA in these two studies. One study has examined the expression of kainate receptor subunit protein levels in schizophrenic brain. Breese et al. (1995) found no differences between persons with schizophrenia and controls using western blot analysis, with an antibody that cross-reacted with all three of the low affinity subunits (gluR5, gluR6, and gluR7). The lack of specificity of this antibody may have prevented the detection of changes of individual subunit proteins.
There are a series of earlier studies that examined binding to the kainate receptor in schizophrenic brain. We found no differences of $\left[{ }^{3} \mathrm{H}\right]$ kainate binding in striatum between individuals with schizophrenia and controls, consistent with a previous report (Noga et al. 1997). While there is a report of decreased $\left[{ }^{3} \mathrm{H}\right]$ kainate binding in the hippocampus and parahippocampal cortex (Kerwin et al. 1990) that is consistent with our findings in prefrontal cortex, there are other reports that have found increased $\left[{ }^{3} \mathrm{H}\right]$ kainate binding in prefrontal cortex. In one study, increased $\left[{ }^{3} \mathrm{H}\right]$ kainate binding was found in BA11 (Deakin et al. 1989) and in another in BA9, 10, and 46 (Nishikawa et al. 1983). Both of these studies used cortical homogenates, whereas we used receptor autoradiography, and our subjects were several decades older than the subjects used in these previous studies, which may account for the differences between our data and these earlier studies.

Decreased kainate receptor expression, and the shift in subunit composition toward receptors with less sensitivity to glutamate, suggest that treatments targeting the kainate receptor may be potentially therapeutic. Because kainate receptor agonists are excitotoxic, drugs that inhibit kainate receptor desensitization may represent a useful strategy to facilitate kainate receptor function (Egebjerg et al. 1991; Wilding and Huettner 1997). This increase in kainate receptor activity may also facilitate NMDA receptor-mediated neurotransmission, and offer yet another approach to the recent augmentation strategies targeting the NMDA receptor in the treatment of schizophrenia.

Several potential limitations need to be considered in the interpretation of these data. As noted above, these subjects are several decades older than have been used in other postmortem studies on glutamate receptor ex- 
pression in schizophrenia, and these results may not generalize to a younger cohort of subjects. A potential confound in all studies in schizophrenia is the possible effects of past antipsychotic exposure. Several animal studies, however, have suggested that neither kainate receptor subunit mRNA (Eastwood et al. 1996; Healy and Meador-Woodruff 1997) nor [ $\left.{ }^{3} \mathrm{H}\right]$ kainate binding (Tarazi et al. 1996) are changed after chronic antipsychotic treatment. The riboprobes used in this study are complementary to regions common for all splice variants and edited kainate subunits, so there may be subtle differences in kainate receptor subunit expression in schizophrenia that cannot be detected in the present study. These differences may have important functional implications, as both splice variants and mRNA editing confer unique pharmacological properties on assembled receptors (Nutt and Kamboj 1994; Paschen et al. 1994; Schiffer et al. 1997; Seeburg 1996; Swanson et al. 1996). For example, the unedited forms of gluR5 and gluR6 display much higher calcium conductance than the edited forms; an increase in subunit editing might decrease kainate receptor-mediated activity (Swanson et al. 1996).

The possibility exists that changes in RNA integrity may account for changes that we have found. However, there are several observations that argue against differential RNA integrity explaining our findings. First, the transcript changes we found in the prefrontal cortex were not seen in the occipital cortex. Further, gluR7 mRNA increased, which would be unlikely if the schizophrenic group had less stable mRNA (which could potentially explain the decreased KA2 finding). Likewise, we recently demonstrated that the AMPA receptor subunit mRNAs are not abnormally expressed in these same subjects (Healy et al. 1998). Taken together, these considerations suggest that these are selective changes in kainate receptor subunit mRNA expression, and are not a result of altered RNA integrity in schizophrenia.

In conclusion, our data support a role for altered kainate receptor expression in elderly in the prefrontal cortex in schizophrenia, and suggest that both total receptor number as well as subunit composition may be abnormal. These findings add to a small but growing body of literature which supports abnormalities of the kainate receptor in schizophrenia.

\section{ACKNOWLEDGMENTS}

This work was supported by MH53327 (JHMW), a Veterans Administration Merit Review Award (VH), and MH45212, AG5138, and AG2219 (KLD). The authors gratefully acknowledge the expert technical assistance of Alan Hogg. Daniel J. Healy, M.D., and Oren Cahlon assisted in earlier versions of this work. A preliminary version of this work was presented at the annual meeting of the Society of Biological Psychiatry, Toronto, Ontario, Canada, May, 1998.

\section{REFERENCES}

Breese CR, Freedman R, Leonard S (1995): Glutamate receptor subtype expression in human postmortem brain tissue from schizophrenics and alcohol abusers. Brain Res 674:82-90

Carlsson M, Carlsson A (1990): Schizophrenia: A subcortical neurotransmitter imbalance syndrome? Schizophrenia Bulletin 16:425-432

Deakin JFW, Slater P, Simpson MDC, Gilchrist AC, Skan, AC, Royston MC, Reynolds GP, Cross AJ (1989): Frontal cortical and left temporal glutamatergic dysfunction in schizophrenia. J Neurochem 52:1781-1786

Eastwood SL, Porter RHP, Harrison PJ (1996): The effect of chronic haloperidol on glutamate receptor subunit (gluR1, gluR2, KA1, KA2, NR1) mRNAs and glutamate binding protein mRNA in rat forebrain. Neurosci Lett 212:163-166

Egebjerg J, Bettler B, Hermans-Borgmeyer I, Heinemann S (1991): Cloning of a cDNA for a glutamate receptor subunit activated by kainate but not AMPA. Nature 351: 745-748

Goff DC, Tsai G, Manoach DS, Coyle JT (1995): Dose-finding trial of D-cycloserine added to neuroleptics for negative symptoms in schizophrenia. Am J Psychiatry 152:1213-1215

Goff DC, Tsai G, Manoach DS, Coyle JT (1999): A placebocontrolled trial of D-cycloserine added to conventional neuroleptics in patients with schizophrenia. Arch Gen Psychiatry 56:21-27

Healy DJ, Haroutunian V, Powchik P, Davidson M, Davis KL, Watson SJ, Meador-Woodruff JH (1998): AMPA receptor binding and subunit $\mathrm{mRNA}$ expression in prefrontal cortex and striatum of elderly schizophrenics. Neuropsychopharmacology 19:278-286

Healy DJ, Meador-Woodruff JH (1997): Clozapine and haloperidol differentially affect AMPA and kainate receptor subunit mRNA levels in rat cortex and striatum. Mol Brain Res 47:331-338

Heresco-Levy U, Javitt DC, Ermilov M, Mordel C, Silipo G, Lichtenstein M (1999): Efficacy of high-dose glycine in the treatment of enduring negative symptoms of schizophrenia. Arch Gen Psychiatry 56:29-36

Hollmann M, Heinemann S (1994): Cloned glutamate receptors. Annu Rev Neurosci 17:31-108

Itil T, Keskiner A, Kiremitci N, Holden JMC (1967): Effect of phencyclidine in chronic schizophrenia. Can J Psychiatry 12:209-212

Javitt DC, Zukin SR (1991): Recent advances in the phencyclidine model of schizophrenia. Am J Psychiatry 148:1301-1308

Javitt DC, Zylberman I, Zukin SR, Heresco-Levy U, Lindenmayer JP (1994): Amelioration of negative symptoms in schizophrenia by glycine. Am J Psychiatry 151:1234-1236

Kerwin R, Patel S, Meldrum B (1990): Quantitative autoradiographic analysis of glutamate binding sites in the hippocampal formation in normal and schizophrenic brain post mortem. Neuroscience 39:25-32

Krystal JH, Karper LP, Seibyl JP, Freeman GK, Delaney R, Bremner JD, Heninger GR, Bowers MB, Charney DS (1994): Subanesthetic effects of the noncompetitive NMDA antagonist ketamine in humans: Psychotomimetic perceptual cognitive and neuroendocrine responses. Arch Gen Psychiatry 51:199-214 
Lahti AC, Holcomb HH, Medoff DR, Tamminga CA (1995): Ketamine activates psychosis and alters limbic blood flow in schizophrenia. Neuroreport 6:869-872

Lerma J (1998): Kainate receptors: an interplay between excitatory and inhibitory synapses. FEBS Lett 430:100-104

Luby E, Gottlieb J, Cohen B, Rosenbaum G, Domino E (1962): Model psychoses and schizophrenia. Am J Psychiatry 119:61-67

Meador-Woodruff JH, Haroutunian V, Powchik P, Davidson M, Davis KL, Watson SJ (1997): Dopamine receptor transcript expression in striatum prefrontal and occipital cortex: focal abnormalities in orbitofrontal cortex in schizophrenia. Arch Gen Psychiatry 54:1089-1095

Meador-Woodruff JH, Healy DJ (2000): Glutamate receptor expression in schizophrenic brain. Brain Res Reviews 31:288-294

Nishikawa T, Takashima M, Toru M (1983): Increased $\left[{ }^{3} \mathrm{H}\right]$ kainic acid binding in the prefrontal cortex in schizophrenia. Neurosci Lett 40:245-250

Noga JT, Hyde TM, Herman MM, Spurney CF, Bigelow LB, Weinberger DR, Kleinman JE (1997): Glutamate receptors in the postmortem striatum of schizophrenic, suicide, and control brains. Synapse 27:168-176

Nutt SL, Kamboj R (1994): RNA editing of human kainate receptor subunits. NeuroReport 5:2625-2629

Paschen W, Hedreen JC, Ross CA (1994): RNA editing of the glutamate receptor subunits gluR2 and gluR6 in human brain tissue. J Neurochem 63:1596-1602
Porter RHP, Eastwood SL, Harrison (1997): Distribution of kainate receptor subunit mRNAs in human hippocampus, neocortex and cerebellum, and bilateral reduction of hippocampal gluR6 and KA2 transcripts in schizophrenia. Brain Res 751:217-231

Schiffer JJ, Swanson GT, Heinemann SF (1997): Rat gluR7 and a carboxy-terminal splice variant, gluR7b, are functional kainate receptor subunits with a low sensitivity to glutamate. Neuron 19:1141-1146

Seeburg PH (1996): The role of RNA editing in controlling glutamate receptor channel properties. J Neurochem 66:1-5

Sokolov BP (1998): Expression of NMDAR1, gluR1, gluR7, and KA1 glutamate receptor mRNAs is decreased in frontal cortex of "neuroleptic free" schizophrenics: Evidence on reversible up-regulation by typical neuroleptics. J Neurochem 71:2454-2464

Swanson GT, Feldmeyer D, Kaneda M, Cull-Candy SG (1996): Effect of RNA editing and subunit co-assembly on single-channel properties of recombinant kainate receptors. J Physiol 492:129-42

Tarazi F, Florijn WJ, Creese I (1996): Regulation of ionotropic glutamate receptors following subchronic and chronic treatment with typical and atypical antipsychotics. Psychopharmacology 128:371-9

Wilding TJ, Heuttner JE (1997): Activation and desensitization of hippocampal kainate receptors. J Neurosci $17: 2713-2721$ 